\title{
慣性力により摩擦力を制御する アザラシ型精密位置決め機構の移動特性*
}

\author{
古谷克 司** 磯 野 秀 明*** \\ Performance of AZARASHI (Seal) Positioning Mechanism with Friction Control by Inertial Force \\ Katsushi FURUTANI and Hideaki ISONO \\ This paper deals with the mobility of AZARASHI (Seal) Mechanism in vacuum. A device of AZARASHI Mechanism with \\ one degree of freedom moves by using the controlled Friction device and one to generate a constant friction. Electromagnets, \\ springs and clamps with piezoelectric actuators have been used for the controlled Friction device. In this paper, the friction was \\ controlled by the perpendicular inertial force using a piezoelectric actuator applied a modified trapezoidal wave. The inertial \\ force on Friction devices restricted the driving frequency of Extension device. In the case of using stainless steel for the device \\ and aluminum for the base, the device stably moves without adhesion.
}

Key words: inertial force, piezoelectric actuator, friction control, vacuum, positioning

\section{1. 緒言}

走査型プローブ顕微鏡(SPM)などのステージには, 真空において も高い分解能と広範囲に移動可能な機構が必要とされている. そ れを実現する方法として，圧電アクチュエータを用いた小型の移 動機構が多数提案されている ${ }^{1) \sim 4)}$. 著者らは, 精密位置決めが可 能なアザラシ型移動機構を提案している ${ }^{5) \sim 8)}$. 本機構は, 一つの 摩擦機構により発生させる一定摩擦力と, その他の摩擦機構によ りオンオフ制御される摩擦力の差を利用して動作する. そのため, インチワーム機構よりも制御素子が少ないという利点を持つ. L 字形に構成した場合には $x y$ 方向への並進だけでなく, 回転方向へ の移動もできる.

一般に，真空における摩擦は大気中と大きく異なる性質を有す る.したがって，本機構を真空中で用いる場合にはしゅう動部の 材質を検討する必要があると考えられる. そのため摩擦力の制御 法は，しゅう動部の材料に依存しないことが望ましい，小形移動 機構における摩擦力の制御には, 磁力 ${ }^{5)}$, 静電力 ${ }^{9)}$, 慣性力 ${ }^{10) 11)}$, 機械的なクランプ機構 ${ }^{8)}$, 超音波加振時の摩擦力変化 ${ }^{12)}$ などを用 いる方法が提案されている.

そこで本論文では，しゅう動部の材料に制限がないように，ア ザラシ型機構の摩擦力制御に慣性力を用いる方法を適用する. 1 自由度機構の基本構造と動作原理について述べた後, さまざまな 摩擦材を用いて真空中での動作特性の測定した結果について述べ る.

\section{2. 移 動 原 理}

\section{1 アザラシ型精密位置決め機構の移動原理}

1 自由度アザラシ型機構の構成を図 1 に示す ${ }^{8)}$. 2 個の摩擦機構 A，B と 1 個の伸縮素子から構成される. 伸縮素子の両端に摩擦機 構を取り付け, それをべース上に置く. 摩擦機構のハッチングは, 摩擦力の強さを表す. 摩擦機構 A は一定摩擦力にされており, 摩

* 原稿受付 平成 21 年 7 月 9 日

**正会員 豊田工業大学 Toyota Technological Institute (名古屋市 天白区久方 2-12-1）, furutani@toyota-ti.ac.jp

***豊田工業大学 Toyota Technological Institute（現，(株)インクス Incs Inc. ; 東京都中央区日本橋堀留町 1-9-11)
擦機構 B のみがオン・オフ制御される. 摩擦機構 A における一定 摩擦力を $F_{\mathrm{A}}($ 同図ハッチング), 摩擦機構 $\mathrm{B}$ の摩擦力を強めた時の 摩擦力を $F_{\mathrm{BO}}\left(\right.$ 同図交差ハッチング), 弱めた時の摩擦力を $F_{\mathrm{BOf}}$ (同 図白)とすると,

$$
F_{\mathrm{BOf} f}<F_{\mathrm{A}}<F_{\mathrm{BOn}}
$$

の関係が成り立つように調整しておく. 右向きに移動する場合 には，以下のサイクルを繰り返す.

(1) 伸縮素子を縮めておき, 摩擦機構 B は弱めておく.

(2) 伸縮素子を伸ばす. 摩擦機構 $\mathrm{A}$ における摩擦力 $F_{\mathrm{A}}$ の方が摩 擦機構 Bにおける摩擦力 $F_{\mathrm{BOff}}$ より大きいため, 摩擦機構 B が右向きに送られる。

(3) 摩擦機構 B を強める.

(4) 伸縮素子を縮める. 摩擦機構 $\mathrm{A}$ における摩擦力 $F_{\mathrm{A}}$ の方が摩 擦機構 $\mathrm{B}$ における摩擦力 $F_{\mathrm{BOn}}$ より小さいため, 摩擦機構 $\mathrm{A}$ が引き寄せられる.これで, (1)の状態に戻る.

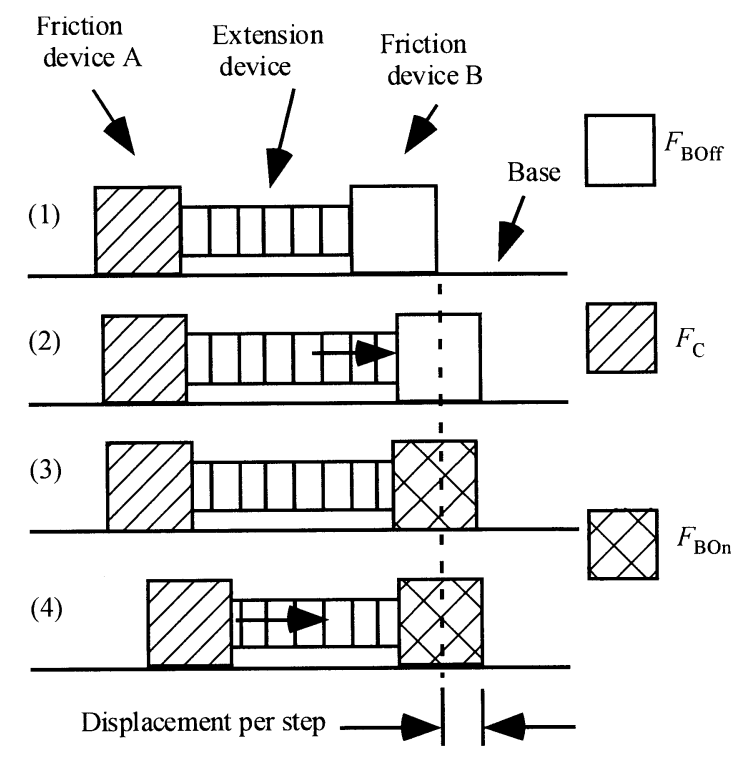

Fig. 1 Principle of movement of AZARASHI mechanism with 1 degree of freedom 


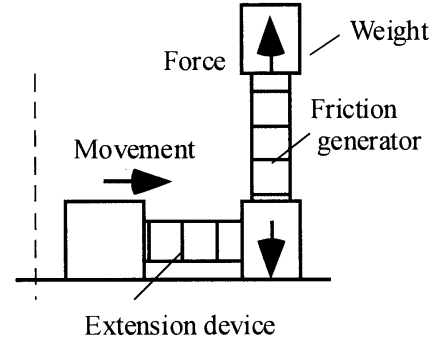

(a) On-friction by extension

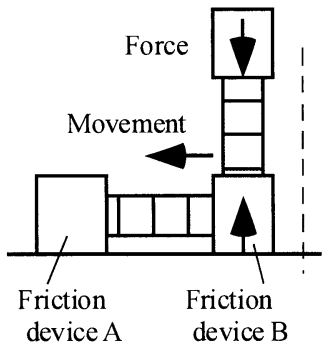

(b) Off-friction by contraction

Fig. 2 Driving principle of AZARASHI Mechanism by using friction controlled by vertical inertial force during contracting Extension device

左向きに移動する場合には，伸縮素子の伸縮を逆にする．この 動作は，アザラシが後足をすりながら移動する様子に似ているた め, アザラシ型機構と呼んでいる.

\section{2 慣性力を利用した摩擦力制御}

慣性力による摩擦力制御を利用したアザラシ型機構の駆動原理 を図 2 に示す.摩擦機構 A と B が移動に用いるための伸縮素子(圧 電素子)でつながれている. 摩擦機構 A は自重による一定摩擦力を 発生する. 摩擦機構 B には先端におもりを取り付けた摩擦発生素 子(圧電素子)が移動方向と垂直な方向に取り付けられている. 同図 (a)のように摩擦発生素子が伸長すると，おもりを押すことで下向 きの慣性力を発生する. それにより垂直抗力が増加し摩擦力が大 きくなる. したがって伸縮素子が収縮すると摩擦機構 A が摩擦機 構 $\mathrm{B}$ 側一引き付けられる. また同図(b)のように摩擦発生素子が収 縮すると，おもりを引きつけることで上向きの慣性力を発生する. それにより垂直抗力が減少し, 摩擦力が小さくなる. したがって 摩擦機構 B が摩擦機構 $\mathrm{A}$ 側へ引き付けられる. 伸縮素子が伸びる ときは同図と逆向きの変位が発生する.

摩擦発生素子の変位と加速度, 伸縮素子の変位を図 3 に示す. 本機構では伸縮素子で移動方向の慣性力が発生すると, 停止する はずのときに移動したり，反対向きに移動することがある．そこ で伸縮素子には立上り，立下りを正弦波状にした変形台形波を印 加し，次式に従い伸縮させた

$$
l_{\mathrm{h}}= \begin{cases}-A \cos 4 \pi f t+L & \left(0 \leq t<\frac{1}{4 f}\right) \\ A+L & \left(\frac{1}{4 f} \leq t<\frac{1}{2 f_{0}}\right) \\ A \cos 4 \pi f\left(t-\frac{1}{2 f_{0}}\right)+L & \left(\frac{1}{2 f_{0}} \leq t<\frac{1}{2 f_{0}}+\frac{1}{4 f}\right) \\ -A+L & \left(\frac{1}{2 f_{0}}+\frac{1}{4 f} \leq t<\frac{1}{f_{0}}\right)\end{cases}
$$

ここで, $f_{0}$ は変形台形波の周波数であり基本波周波数と呼び, $f$ は立上り，立下り波形の周波数であり立上り周波数と呼ぶことに する.

衝撃的な慣性力を利用する場合には，摩擦発生素子を同時に急 速変形させることが望ましい ${ }^{10)}$ ．本機構では慣性力が発生しない 条件で駆動する．したがって，摩擦発生素子に次式のように変形 台形波状に伸縮させた。

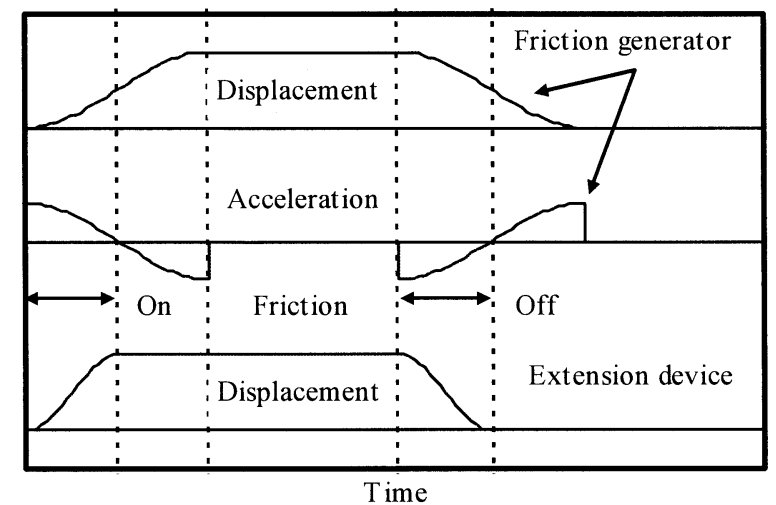

Fig. 3 Waveforms of displacements and accelerations of piezoelectric actuators

$$
l_{\mathrm{v}}= \begin{cases}-A \cos 2 \pi f t+L & \left(0 \leq t<\frac{1}{2 f}\right) \\ A+L & \left(\frac{1}{2 f} \leq t<\frac{1}{2 f_{0}}\right) \\ A \cos 2 \pi f\left(t-\frac{1}{2 f_{0}}\right)+L & \left(\frac{1}{2 f_{0}} \leq t<\frac{1}{2 f_{0}}+\frac{1}{2 f}\right) \\ -A+L & \left(\frac{1}{2 f_{0}}+\frac{1}{2 f} \leq t<\frac{1}{f_{0}}\right)\end{cases}
$$

このときの伸縮の加速度は,

$$
\ddot{l}_{\mathrm{v}}= \begin{cases}(2 \pi f)^{2} A \cos 2 \pi f t & \left(0 \leq t<\frac{1}{2 f}\right) \\ 0 & \left(\frac{1}{2 f} \leq t<\frac{1}{2 f_{0}}\right) \\ (2 \pi f)^{2} A \cos 2 \pi f\left(t-\frac{1}{2 f_{0}}\right) & \left(\frac{1}{2 f_{0}} \leq t<\frac{1}{2 f_{0}}+\frac{1}{2 f}\right) \\ 0 & \left(\frac{1}{2 f_{0}}+\frac{1}{2 f} \leq t<\frac{1}{f_{0}}\right)\end{cases}
$$

である. 摩擦機構の伸縮の半分の時間で伸縮素子が伸縮するため, その間の垂直方向慣性力は一方向となる. したがって, 摩擦力の 制御が可能となる.

\section{3. 実 験 装 置}

実験に用いたアザラシ型機構の外観を図 4 に示す．全体の寸法 は $50 \mathrm{~mm} \times 20 \mathrm{~mm} \times 34 \mathrm{~mm}$ ，質量は $62 \mathrm{~g}$ (一定摩擦機構 $25 \mathrm{~g}$ ，制御用摩 擦機構の下側 $11 \mathrm{~g}$, 上側のおもり $11 \mathrm{~g}$, 圧電素子各 $5 \mathrm{~g}$, 残りは配線 など)である. 一定摩擦機構と制御摩擦機構の質量はほぼ等しい。 金属部分は SUS304 とした. V 溝に走行面をボルトで取り付けて ガイドにした. 圧電素子にはNEC トーキン製 AE0505D16(100V印 加時の変位量 $11.6 \mu \mathrm{m})$ を用いた. 走行面の材質には, アザラシ型機 構のしゅう動部と同じ SUS304 に加え，真空中でしゅう動する部 分に用いられている4 種類の材質 $\left(\mathrm{TiN}, \mathrm{MoS}_{2}, \mathrm{TiO}_{2}, \mathrm{~A} 5052\right)^{13) 14}$ を用いた. $\mathrm{TiN}, \mathrm{MoS}_{2}$ はイオンプレーティング， $\mathrm{TiO}_{2}$ は溶射によ り SUS304 基板上に膜を形成した. 各走行面の大気中の摩擦係数, 算術平均表面粗さ, 膜厚を表 1 に示す. いずれの摩擦材も表面粗 さはサブミクロン以下で，同等な条件であった，V ガイドを傾け てアザラシ型機構が滑り出すときの摩擦角を測定することで大気 中の摩擦係数を測定した. 摩擦係数は 0.12〜0.73 と大きく異なっ 


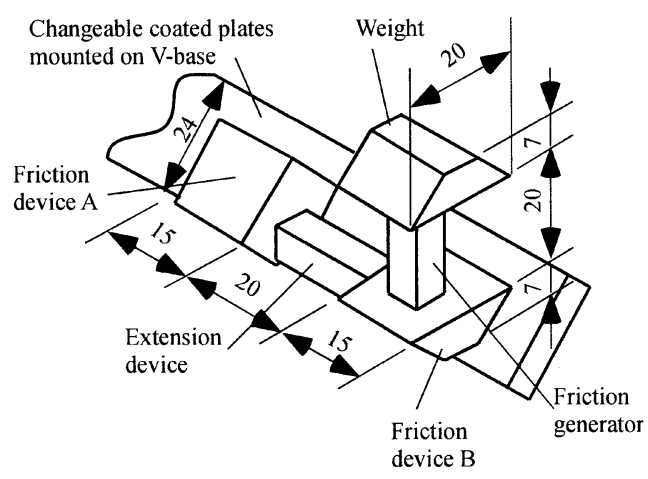

Fig. 4 Appearance of AZARASHI mechanism with 1 degree of freedom (Front coated plate is omitted.)

Table 1 Static friction coefficients against SUS304 in air

\begin{tabular}{|c|c|c|c|}
\hline Material & $\begin{array}{ll}\text { Static } & \text { friction } \\
\text { coefficients in air } \\
(\text { dispersion \%) }\end{array}$ & $\begin{array}{l}\text { Thickness of } \\
\text { coating } \mu \mathrm{m}\end{array}$ & $\begin{array}{l}\text { Surface } \\
\text { roughness } \\
\mu \mathrm{m} R a\end{array}$ \\
\hline A5052 & $0.73(27)$ & - & 0.052 \\
\hline $\begin{array}{c}\mathrm{TiN} \\
\text { (coated) }\end{array}$ & $0.52(4)$ & $2-4$ & 0.031 \\
\hline SUS304 & $0.39(13)$ & - & 0.023 \\
\hline $\begin{array}{c}\mathrm{TiO}_{2} \\
\text { (coated) }\end{array}$ & $0.22(5)$ & 250 & 0.078 \\
\hline $\begin{array}{c}\mathrm{MoS}_{2} \\
\text { (coated) }\end{array}$ & $0.12(6)$ & 1 & 0.033 \\
\hline
\end{tabular}

$\mathrm{TiN}, \mathrm{MoS}_{2}$ : ion plating; $\mathrm{TiO}_{2}$ : thermal spraying

た. コーティングしたしゅう動面では摩擦係数のばらつきは小さ かった.

装置の全体構成を図 5 に示す. 高真空槽を用いて真空中(3.1〜 $\left.7.3 \times 10^{-5} \mathrm{~Pa}\right)$ と大気中で動作試験を行った. 変位は光学式変位振動測 定器(ツィンマー社製 MODEL100H, 測定範囲 $1 \mathrm{~mm}$ ，分解能 $1 \mu \mathrm{m}$ ) を使用して，チャンバののぞき空から測定した. 2 分割した明暗パ ターンを観察し，その比率により変位を測定する原理であるため, ガラスを介することによる測定変位への影響は非常に小さい. 摩 擦機構 A 側への移動を正とした.

\section{4. 実 験 結 果}

\section{1 慣性力を利用した摩擦力制御}

まず，上下方向の運動のみについて考える. 摩擦発生素子の加 速度を大きくすると，機構全体が跳躍する．したがって，これを 正弦波状に伸縮させ, 跳躍しない最大加速度以下で駆動すること にする. 摩擦力制御を行うときのモデルは図 6 となる.このとき の運動方程式は,

$$
\left\{\begin{array}{l}
m_{1} \ddot{x}_{1}=-F-\int_{x_{2}}^{x_{1}} \rho \ddot{x}_{\mathrm{p}} d x_{\mathrm{p}}-\int_{x_{2}}^{x_{1}} \rho g d x_{\mathrm{p}}-m_{1} g \\
m_{2} \ddot{x}_{2}=F+N-m_{2} g \\
\ddot{x}_{\mathrm{p}}=\frac{\ddot{x}_{1}-\ddot{x}_{2}}{x_{1}-x_{2}} x_{\mathrm{p}}+\ddot{x}_{2} \\
m_{\mathrm{p}}=\rho\left(x_{1}-x_{2}\right)
\end{array}\right.
$$

となる. ただし， $m_{1}$ は摩擦発生素子上部に取り付けられたおもり の質量, $m_{2}$ はベースと接する側の制御摩擦機構の質量, $x_{1}$ と $x_{2}$ は おもりとそれ以外の部分の変位, $x_{\mathrm{p}}$ は圧電アクチュエータの微小 部分の変位, $F$ は圧電アクチュエータが発生する力, $N$ は垂直抗 力, $\rho$ は圧電アクチュエータの単位長さあたりの質量, $m_{\mathrm{p}}$ は圧電ア クチュエータの質量, $f$ と $A$ は圧電アクチュエータの伸縮の周波数 と振幅である. $m_{2}$ が浮き上がらないときに $x_{2}=0, \quad \ddot{x}_{2}=0$ であるこ

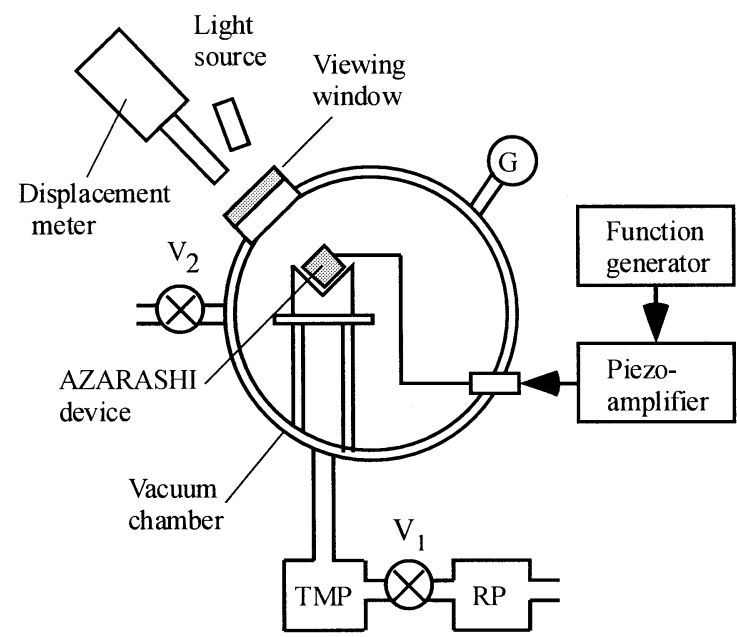

Fig. 5 Setup for mobility test in vacuum; G: ionized vacuum gauge, TMP: turbo molecular pump, RP: rotary pump, $V_{1}, V_{2}$ : valves

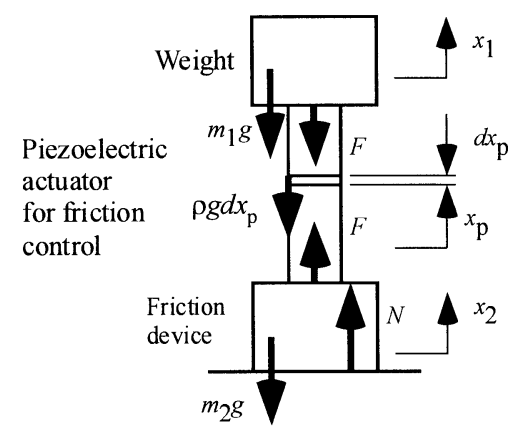

Fig. 6 Model of friction control by inertial force

とを考慮して整理すると，

$\left\{\begin{array}{l}m_{1} \ddot{x}_{1}=-F-\frac{m_{\mathrm{p}}}{2} \ddot{x}_{1}-\left(m_{\mathrm{p}}-m_{1}\right) g \\ 0=F+N-m_{2} g\end{array}\right.$

となる. さらに $N \geq 0$ であるので, 式(4)を代入すると,

$$
N=\left(m_{1}+m_{2}+m_{\mathrm{p}}\right) g+\left(m_{1}+\frac{m_{\mathrm{p}}}{2}\right)(2 \pi f)^{2} A \cos 2 \pi f \geq 0
$$

となる. $t=1 /(2 f)$ のときに式(7)が最小になることから，

$$
N=\left(m_{1}+m_{2}+m_{\mathrm{p}}\right) g-\left(m_{1}+\frac{m_{\mathrm{p}}}{2}\right)(2 \pi f)^{2} A \geq 0
$$

である. 周波数は正であることを考慮してこれを解くと立ち上が り周波数の範井は,

$$
0<f \leq \frac{1}{2 \pi} \sqrt{\frac{m_{1}+m_{2}+m_{\mathrm{p}}}{m_{1}+m_{\mathrm{p}} / 2} \frac{g}{A}}=\frac{1}{2 \pi} \sqrt{\frac{m_{1}+m_{2}+m_{\mathrm{p}}}{2 m_{1}+m_{\mathrm{p}}} \frac{2 g}{d V}}
$$

となる.ここで, $d$ は圧電素子の変位を線形とみなした場合の単位 電圧あたりの伸縮量である。ここで今回用いた装置では $m_{1}=m_{2}=11 \mathrm{~g}, m_{\mathrm{p}}=5 \mathrm{~g}$ であり, カタログ值 ${ }^{15}$ から $d=1.16 \times 10^{-7} \mathrm{~m} / \mathrm{V}$ と 寸る. これらを式(9)に代入すると, 入力電圧の振幅 $V$ と周波数 $f$ の関係は, 


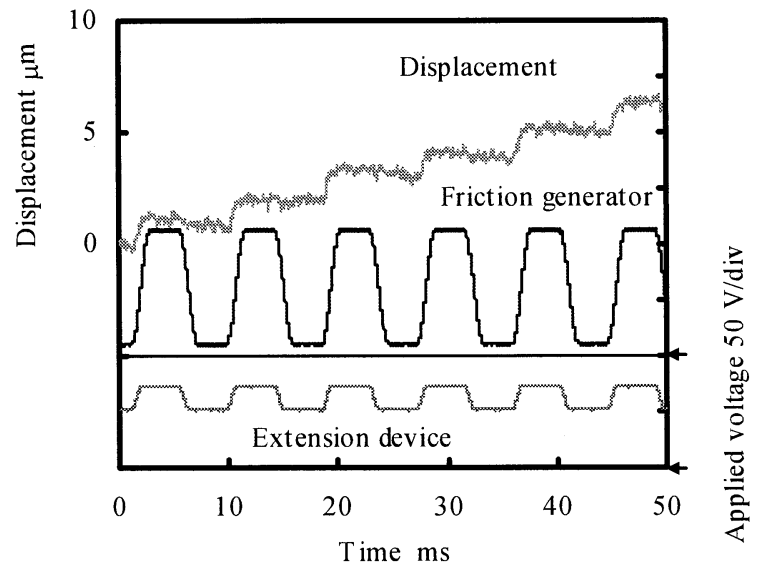

Fig. 7 Example of displacement in air and applied voltage

$$
0<f \leq 2.07 \times 10^{3} / \sqrt{V}
$$

となる.

伸縮素子の伸縮にともなう慣性力で機構が前後方向一変位しな いためには, 変位する時間を十分にとる必要がある. したがって, 立上り周波数 $f$ が小さいほうが望ましいが, 摩擦力を得るための慣 性力が小さくなる，そこで，電圧を大きく設定することで立ち上 がり周波数を低くして, 大きな摩擦力が得られるようにした. 使 用した圧電素子駆動アンプの出力範囲が 0 〜 $120 \mathrm{~V}$ であるため, 摩 擦発生素子への印加電圧のオフセットを $60 \mathrm{~V}$, 振幅を $50 \mathrm{~V}$ とした. 式(11)からは立ち上がり周波数の上限は $293 \mathrm{~Hz}$ となる. 電気的な 接触検知により測定したところ，浮上しない立ち上がり周波数の 上限は計算值より高い $340 \mathrm{~Hz}$ であった. 配線により下向きに引っ 張られる力が影響していると考えられる.

\section{2 移動特性}

次に, 伸縮機構も動作させて前後方向一移動する場合を考える. 式(11)を満たす範囲および使用したファンクションジェネレータ で設定可能な值として, 摩擦発生素子一印加する電圧の立上り周 波数を $287.5 \mathrm{~Hz}$ とした. 伸縮素子は立上り周波数を $575.0 \mathrm{~Hz}$ とし た. 両方の基本周波数は $115.0 \mathrm{~Hz}$ とした. 予備実験の結果, 電圧 振幅が大きい場合には伸縮素子で発生する慣性力により反対向き に移動することがあった，そのため, 電圧振幅を $2 \sim 15 \mathrm{~V}$ の間で変 化させた. 以下のすべての害験において, 摩擦発生素子への印加 電圧のオフセットを $60 \mathrm{~V}$ ，振幅を $50 \mathrm{~V}$ で一定にした. 各走行面を 用いて大気中, 真空中で実験を行った. 図 7 に A5052 ガイド上で 駆動用電圧振幅を $10 \mathrm{~V}$ として大気中で駆動したときの変位を示す 右軸の矢印が各印加電圧の $0 \mathrm{~V}$ を示している. うず電流式変位セン サを用いて摩擦機構 $A$ の変位を測定した. 1 周期ごとの階段状変 位になっており，アザラシ型機構の原理にしたがって動作したと 言える.

真空と大気中とで各ベースを用いて，24周期分の移動を 2 往復 ずつ行った．移動の例を図 8 に示す. 伸縮素子への印加電圧振幅 は $15 \mathrm{~V}$ とした. 同図に示した例では，真空中で $\mathrm{MoS}_{2}$ のベースを 用いた場合には，前進，後退の変位に差があった，金属のベース を用いた場合には，移動量は安定していた．いずれの場合でも変 位が直線的に増減していることより，同一条件下では 1 周期あた りの変位は安定していると言える. 摩擦力発生機構のみを動作さ せた場合には原理的にはどちらにも動かないはずであるが, $\mathrm{MoS}_{2}$ のベース上では後退方向に移動した. したがって，摩擦係数が小

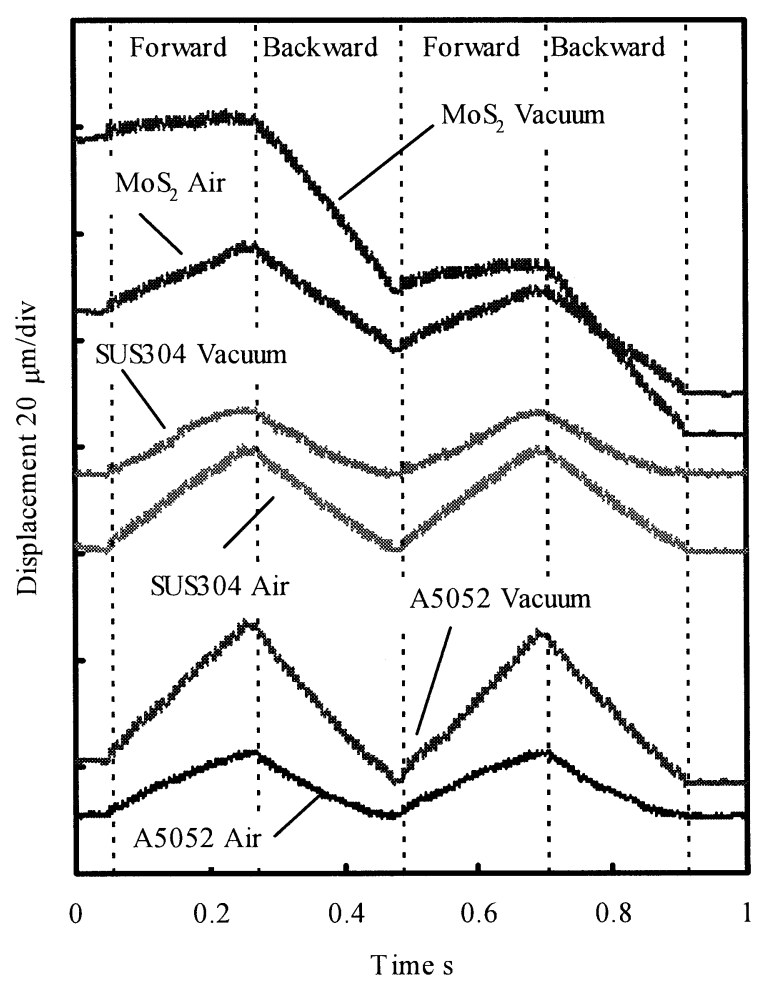

Fig. 8 Examples of displacement of reciprocating motions at $14 \mathrm{~V}$ as applied voltage amplitude to extension device

さい場合には, ベースまたは摩擦発生機構のわずかな傾きでも移 動量に影響を与えると考えられる.

図 8 の実験を伸縮素子の電圧振幅を変えて行った結果を図 9 に 示す. 縦軸は 1 周期あたりの变位である. A5052 ガイド上におけ る変位と印加電圧振幅の関係を同図(a)に示す．前進，後退の変位 量に差はなく, 印加電圧振幅の増加に従い変位は直線的に増加し た. 大気中の変位量の方が小さかった. 印加電圧振幅が $15 \mathrm{~V}$ のと きに急に真空中の前進後退ともに変位が低下したのは, 伸縮方向 の加速度が大きくなり，摩擦を強くしたときでも摩擦機構 B が駆 動方向と逆向きに移動したことが原因であると考えられる. SUS304ガイド上におうける変位と印加電圧振幅の関係を図9(b)に示 す. 大気中では駆動用印加電圧に比例した変位が得られた.この 2 つのことから慣性力による摩擦力制御が有効であったと言える. 一方, 同図の真空中における変位から, 真空中では印加電圧が小 さいときに移動できないことが明らかとなった。しゅう動部が同 じ金属である場合, 凝着が起きや寸くなる. しかし, 駆動用入力 が大きくなり凝着した部分が断ち切られると移動できる. このた めに, 印加電圧が低い場合には移動できなかったと考えられる. 変位し始める電圧以上では, 変位は直線的に増加した. したがっ て, 変位が大きいときには凝着の影響は無視できると考えられる. $\mathrm{MoS}_{2}$ ガイド上における変位と印加電圧振幅の関係を同図(c)に示 す. 大気中でも最大静止摩擦係数が最も小さく, 真空中の方がさ らに小さくなった. 大気中, 真空中ともに前進方向だけの変位が 減少したため, ベースなどの傾きの影響を大きく受けたと考えら れる.

大気中および真空中における变位の駆動電圧に対する変化率を 図 10 に走行面の材質ごとに示す. 図 9 の回帰直線の傾きとして求 めた. 真空中で摩擦係数が小さい $\mathrm{MoS}_{2}$ や $\mathrm{TiO}_{2}$ を用いると, 向き により変位が大きく異なった. 特に摩擦係数の小さい $\mathrm{MoS}_{2}$ は大気 


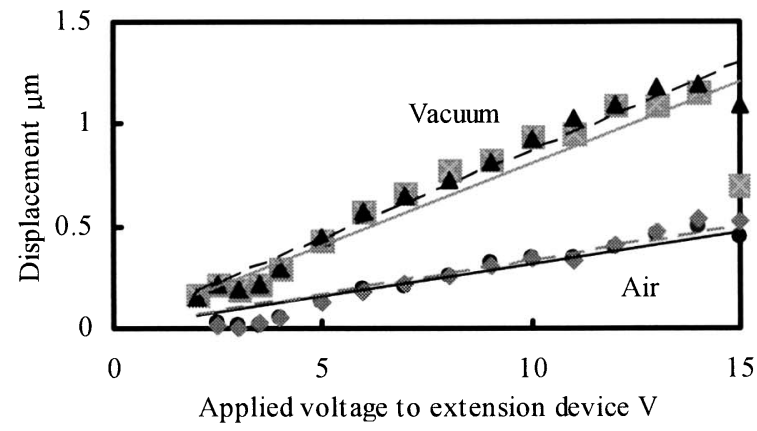

(a) On A5052

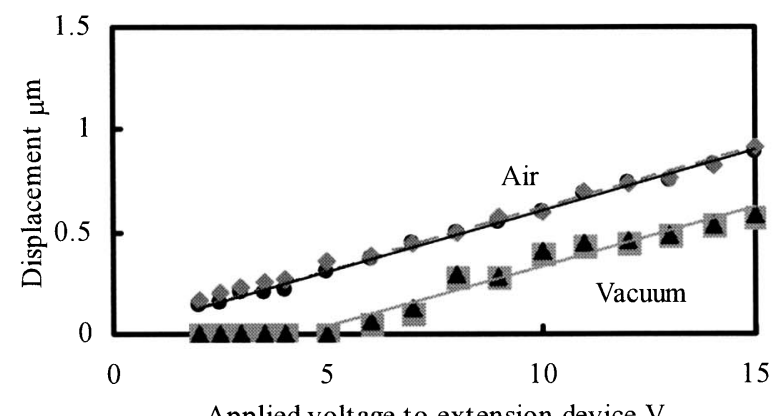

Applied voltage to extension device V

(b) On SUS304

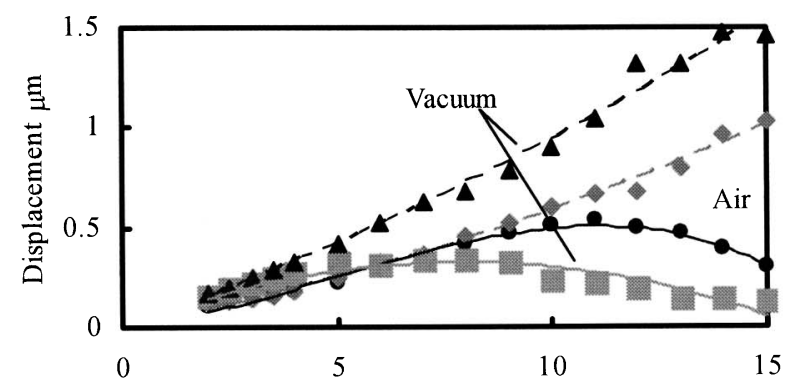

Applied voltage to extension device V

(c) On $\mathrm{MoS}_{2}$ coating

Fig. 9 Relationship between displacement and applied voltage to extension device ( $\bullet$ : forward in air, $\bullet$ : backward in air, forward in vacuum, $\boldsymbol{\Delta}$ : backward in vacuum; solid line: forward, dashed line: backward)

中でも同様の傾向があった，また大気中における摩擦係数が大き いTiN でも起こった. 一方, A5052 は真空におうける変位が大きく, 向きによる変位の差も小さかった. したがって真空中の動作に最 も適していると考えられる．いずれの場合にも，移動中の真空度 の変化は観察されなかった。

\section{5. 結言}

本論文では，アザラシ型位置決め機構の摩擦力の制御法として 慣性力を用い，大気中と真空中の移動特性を調べた. 本研究の結 果をまとめると以下のようになる.

(1) アザラシ型機構の摩擦力制御の方法として慣性力を使う方 法を提案し，有効であることを実験で明らかにした。

(2) 摩擦係数が大きい方がアザラシ型機構の動作に適している. しかし同種金属では凝着が起こりやすいため適さない.

(3)摩擦係数が小さいと前進, 後退の変位が異なる傾向があった. これは真空中で特に顕著であった。

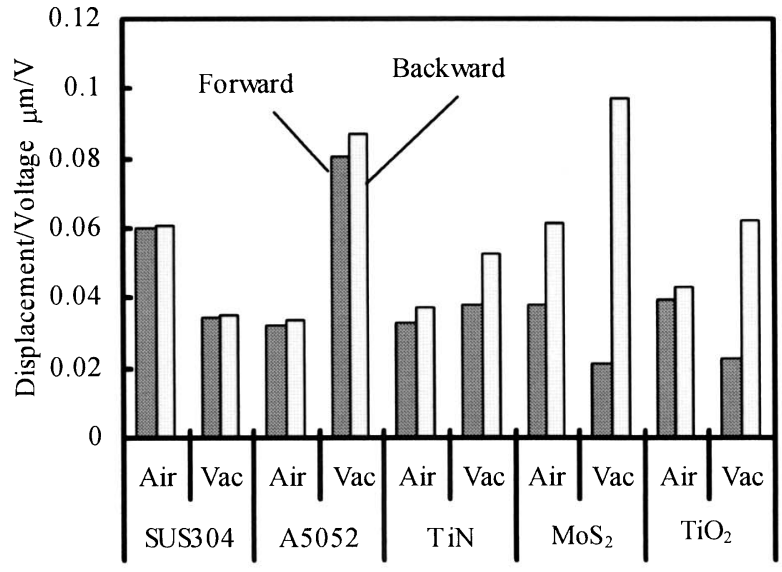

Fig. 10 Ratio of displacement to applied voltage to extension device (Vac: vacuum)

\section{謝辞}

本研究の一部には文部科学省科学研究費補助金特定領域研究 「アクチュエータ」(課題番号 16078214)および文部科学省私立大 学戦略的研究基盤形成支援事業「サステイナブル機械システム研 究センター」補助金を用いました．記して感謝いたします。

\section{参 考 文 献}

1) Y. Yamagata, T. Higuchi, H. Saeki, H. Ishimaru: Ultrahigh vacuum precise positioning device utilizing rapid deformations of piezoelectric elements, J. Vac. Sci. Technol., A8, 6, (1990) 4098.

2) G. W. Stupian, M. S. Leung: The Use of a Linear Piezoelectric Actuator for Coarse Motion in a Vacuum Compatible Scanning Tunneling Microscope, J. Vac. Sci. Technol., A7, 4 ,(1989) 2895.

3) N. Shimizu, T. Kimura, T. Nakamura, I. Umebu: An ultrahigh vacuum scanning tunneling microscope with a new inchworm mechanism, J. Vac. Sci. Technol., A8, 1, (1990) 333.

4) O. Fuchiwaki, H. Aoyama: Flexible micro-processing by multiple miniature robots in SEM vacuum chamber, Proc. IEEE Int. Sympo. Micromechatronics and Human Science, Nagoya, Japan, (2000) 145.

5) K. Furutani, M. Furuichi, N. Mohri: Coarse motion of 'seal mechanism' with three degrees of freedom by using difference of frictional force, Meas. Sci. Technol., 12, 12, (2001) 2147.

6) K. Furutani, N. Ohta, K. Kawagoe: Coarse and Fine Positioning Performance of L-shaped Seal Mechanism with 3 Degrees of Freedom, Meas. Sci. Technol., 15, $1,(2004) 103$.

7) K. Furutani and K. Kawagoe: Improvement of Positioning Performance of AZARASHI (Seal) Mechanism with Three Degrees of Freedom, Trans. Inst. Electrical Eng. Trans. Inst. Elect. Engrn. Jpn., 126-E, 4, (2006) 131 (in Japanese).

8) K. Furutani, N. Ohta and A. Furuta: Improvement of Resolution of AZARASHI (Seal) Mechanism by Current Pulse Drive, J. Jpn. Soc. Precis. Eng., 74, 4, (2008) 411 (in Japanese)

9) S. Konishi, M. Munechika, T. Sawai and K. Yoshifuji: Electrostatic Controlled Linear Inchworm Actuato, Trans. Inst. Elect. Engrn. Jpn., 122-E, 12, (2002) 560 (in Japanese)

10) T. Higuchi, K. Furutani, Y. Yamagata K. Kudoh and M. Ogawa: Improvement of Velocity of Impact Drive Mechanism by Controlling Friction, J. Jpn. Soc. Precis. Eng., 58, 8, (1992) 1327 (in Japanese).

11) H. Isobe, S. Katoh, A. Kyusojin and T. Moriguchi: Development of Piezoelectric $\mathrm{XY} \gamma$ Positioning Device using Impulsive Force. (2nd Report). Improvement of Motion Characteristic with Friction Control, J. Jpn. Soc. Precis. Eng., 64, 3, (1998) 408 (in Japanese).

12) A. Guha, S. Kim, A. L. de Lozanne: Novel frictionless approach mechanism for a scanning tunneling microscope, Rev. Sci. Instrum., 74, 10, (2003) 4384

13) M. Sasaki, I. Nakamura, I. Takano and Y. Sawada: Dependence on Vacuum Pressure for Tribological Properties of $\mathrm{Ti}_{1} \mathrm{TiO}_{2}$ and $\mathrm{TiN}$ Thin Film, Trans. Inst. Elect. Engrn. Jpn., 123-A, 11, (2003) 1108 (in Japanese).

14) T. Niino, S. Funami and M. Michihata: Development of Ultra-high Vacuum Compatible Rotary Feedthrough Using Ultrasonic Motor - Improvement of Durability by Using Aluminum Rotor -, 2006 JSPE Autumn Meeting, (2006) 939 (in Japanese).

15) NEC Tokin: Multilayer Piezoelectric Actuators, P0946MPACVOL04E (2008). 